\title{
In vitro evaluation of a prodrug approach for Gly-D-P18, a host defence peptide and novel anticancer agent
}

\author{
$\mathrm{A} \mathrm{Hsu}^{1 *}$, Marc Devocelle${ }^{2}$, Joseph Ward ${ }^{3}$, Stephen Keely ${ }^{3}$ \\ From International Conference for Healthcare and Medical Students (ICHAMS) 2013 \\ Dublin, Ireland. 11-12 October 2013
}

\section{Background}

Host defence peptide (HDP) has multiple properties [1,2] potentiating it as a novel anticancer agent. However disadvantages include systemic toxicity [3]. To address this, a prodrug was developed and the aim was to assess toxicity differentials between this prodrug and its active peptide component on T84 colonic carcinoma cells. Prodrug bio activation mechanism was also assessed by use of a Cathepsin B inhibitor.

\section{Methods}

Two peptides were provided: Gly-D-P18 and its prodrug form. The prodrug, containing a linker which will serve as substrate for a tumour associated protease, Cathepsin B, and activate the drug. T84 cell lines were cultured separately with Gly-D-P18 and its pro drug at concentrations of $1 \mu \mathrm{M}$ and $10 \mu \mathrm{M}$ over 24 hours. Effects were evaluated by LDH assay, Transepithelial resistance and Electrophysiological measurements. Cathepsin B inhibitor was also incubated, at concentration of $10 \mu \mathrm{M}, 1 \mu \mathrm{M}, 200 \mathrm{nM}$, and $4 \mathrm{nM}$ with pro drug on T84 cells over 24 hours and their effects assessed by transepithelial resistance and LDH measurement.

\section{Results}

Pro drug caused a drop to $74.45 \%$ of initial resistance for $1 \mu \mathrm{M}(\mathrm{n}=5)$ and $22.56 \%$ for $10 \mu \mathrm{M}(\mathrm{n}=5)$ concentrations, in comparison to Gly-D-P18 with $52.33 \%(\mathrm{n}=5)$ and $21.676 \%(\mathrm{n}=5)$ respectively. Also, the use of $10 \mu \mathrm{M}$ prodrug with Cathepsin B inhibitor at $10 \mu \mathrm{M}(\mathrm{n}=3), 1 \mu \mathrm{M}$ $(\mathrm{n}=3), 200 \mathrm{nM}(\mathrm{n}=3), 4 \mathrm{nM}(\mathrm{n}=3)$ concentrations resulted in a drops to $34.12 \%, 26.974 \%, 30.009 \%, 25.977 \%$ of initial resistance respectively, compared to $26.804 \%$ of initial resistance from standalone prodrug $(\mathrm{n}=3)$ treatment. No effects were seen with regards to LDH release or chloride secretion.

\section{Conclusions}

While the prodrug had comparatively decreased resistance drop, inconclusive results and limitations indicated need for further experimentation. In future, one could include usage of wider range of viability tests and comparisons against treatment with prodrug with uncleavable linkers as well as on healthy cells.

\section{Authors' details}

${ }^{1}$ Royal College of Surgeons in Ireland, 123 St. Stephen's Green, Dublin 2. Ireland. ${ }^{2}$ School of Pharmacy, Royal College of Surgeons in Ireland, 123 St. Stephen's Green, Dublin 2. Ireland. ${ }^{3}$ RCSI Molecular Medicine Laboratory, Beaumont Hospital, Dublin 9. Ireland.

\section{Published: 14 January 2015}

\section{References}

1. Jenssen H, Hamill P, Hancock REW: Peptide antimicrobial agents. Clin Microbiol Rev 2006, 19:491-511.

2. Hancock R, Diamond G: The role of cationic antimicrobial peptides in innate host defences. Trends Microbiol 2000, 9:402-410

3. Bowdish D, Davidson D, Hancock R: A re-evaluation of the Role of Host Defence Peptides in Mammalian Immunity. Current Protein and Peptide Science 2005, 6:35-51

\section{doi:10.1186/1753-6561-9-S1-A41}

Cite this article as: Hsu et al: In vitro evaluation of a prodrug approach for Gly-D-P18, a host defence peptide and novel anticancer agent. BMC Proceedings 2015 9(Suppl 1):A41. 